ISSN : 2580-3220, E-ISSN : 2580-4588

J. Mandiri., Vol. 2, No. 1, Juni 2018 (1 - 22)

(C)2018 Lembaga Kajian Demokrasi

dan Pemberdayaan Masyarakat (LKD-PM)

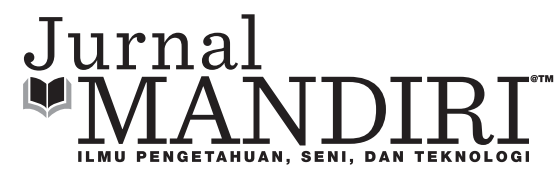

\title{
PENGARUH DISIPLIN KERJA DAN MOTIVASI TERHADAP KINERJA KARYAWAN PADA PT. BANK RAKYAT INDONESIA CABANG PAMULANG
}

\author{
Kenny Astria \\ Fakultas Ekonomi Universitas Pamulang \\ kennyastria@gmail.com
}

\begin{abstract}
Abstrak
Penelitian ini bertujuan untuk mengetahui pengaruh didiplin kerja dan motivasi secara parsial maupun secara simultan terhadap kinerja karyawan pada PT. Bank Rakyat Indonesia Cabang Pamulang. Metode yang digunakan adalah explanatory research, dan pengujian hipotesis. Dengan teknik survei, menyebar kuesioner dengan skala Likert. Teknik penentuan memakai sampling jenuh dengan 60 responden. Teknik analisis data yang digunakan analisis deskriptif dan analisis statistik inferesial yaitu: 1.Uji Validitas dan Reliabilitas, 2. Analisis Regresi Berganda, 3. Analisis Koefisien Determinasi $\left(R^{2}\right)$, 4. Pengujian Hipotesis dengan Uji Parsial (uji t) dan Uji Simultan (uji F). Hasil Pengujian dan analisisnya adalah sebagai berikut:

1. Terdapat pengaruh positif dan signifikan antara disiplin kerja terhadap kinerja karyawan, dengan korelasi positif 0,628 dan kontribusi sebesar 39,4\%. Dan nilai thitung sebesar 6,145 dengan probability signifikansi t sebesar 0,000.

2. Terdapat pengaruh positif dan signifikan antara motivasi terhadap kinerja karyawan, dengan korelasi positif 0,579 dan kontribusi sebesar 33,5\%. Dan nilai thitung sebesar 5,407 dengan probability signifikansi t sebesar 0,000.

3. Terdapat pengaruh positif dan signifikan antara disiplin kerja dan motivasi secara bersama-sama terhadap kinerja karyawan dengan korelasi positif 0,684 dan mempunyai kontribusi pengaruh sebesar 46,8\% dan sisanya 53,2\% dipengaruhi faktor lain yang tidak diteliti. Dan nilai $F_{\text {hitung }}$ sebesar 25,116 dengan signifikan F sebesar 0,000.
\end{abstract}

Kata Kunci : Disiplin Kerja, Motivasi dan Kinerja Karyawan.

\section{PENDAHULUAN}

\section{Latar Belakang}

Dalam dunia bisnis setiap perusahaan dituntut untuk mampu menghasilkan kinerja perusahaan yang baik, meningkat dan menghasilkan output yang optimal. Begitu pula faktor sumber daya yang dimiliki harus mendukung upaya perusahaan dalam menghasilkan profit margin yang diharapkan, tidak terkecuali dengan sumber daya manusianya, dimana sekarang ini sudah masuk pada tataran harus mampu berkompetisi secara global sehingga sumber daya manusia memegang peranan yang sangat penting dalam menuju kompetisi yang 
tajam ini.

Keberadaan karyawan atau pegawai didalam sebuah organisasi atau perusahaan juga sangat menentukan tingkat keberhasilan dalam melaksanakansemuaproseskegiatanperusahaan baik itu prusahaan yang menghasilkan produk (Manufacturer) maupun perusahaan yang bergerak disektor jasa termasuk perusahaan yang bergerak disektor perbankan. Sehingga tidak heran apabila tuntutan perusahaan pasa aspek kemampuan sumber daya manusianya sangat tinggi mengingat kompetisi persaingan juga sangat tinggi. Dengan demikian perusahaan juga dituntut mampu mengelola dengan baik semua asset yang dimiliki termasuk sumber daya manusia yang kompeten guna memastikan seluruh karyawan memiliki daya guna yang diinginkan oleh perusahaan dan selaras dengan tujuan perusahaan untuk memperoleh hasil semaksimal mungkin.

Pegawai atau karyawan sebagai asset bagi perusahaan harus dikelola dengan baik. Pengelolaan yang benar dan tepat akan menghasilkan kinerja yang optimal dan produktif, oleh sebab itu manajemen perusahaan harus selalu mendorong agar semua dapat produktif dalam menjalankan tugas dan kewajibannya sesuai dengan job description yang telah ditetapkan oleh perusahaan.

Dalam dunia perbankan di Indonesia, dimana semua transaksi keuangan terkait dengan kinerja bisnis semakin maju, penggunaan teknologi semakin bervariasi, memungkinkan semuanya berjalan dengan cepat dan proses tidak berbelit-belit. Perusahaan yang memiliki prestasi yang sangat baik akan mampu meningkatkan kepercayaan masyarakat terutama pada aspek penambahan nasabah atau pelanggan sebagai akibat dari membaiknya kinerja perusahaan tersebut.

PT. Bank Rakyat Indonesia sendiri sebagai perusahaan perbankan yang mengelola keuangan dan penggalangan dana nasabah serta program yang terukur, harus mampu menjadikan lembaga keuangan bank tersebut meraih kondisi kinerja yang baik. Berdasarkan Undang-Undang Perbankan No. 7 tahun 1992 dan Peraturan Pemerintah RI No. 21 tahun 1992 status Bank Rakyat Indonesia berubah menjadi perseroan terbatas yang sampai saat ini PT. BRI (Persero)Tbk harus tetap konsisten dalam memberikan pelayanan kepada semua elemen masyarakat, baik pada masyarakat kecil maupun menengah ke atas. Pada masyarakat kecil peranan dan program perusahaan harus dapat melayani dengan baik seperti dengan memberikan fasilitas kredit kepada golongan pengusaha kecil.

Terkait dengan dengan implementasi Masyarakat Ekonomi ASEAN (MEA) adalah kesiapan sumber daya manusia maka Bank Rakyat Indonesia senantiasa melakukan kegiatan perbankan dengan pengutamakan pelayanan yang prima kepada masyarakat sebagai nasabahnya. Sumber daya manusia juga memiliki posisi sangat strategis dalam organisasi, artinya unsur manusia memegang peranan penting dalam melakukan aktivitas untuk pencapaian tujuan. Untuk itulah maka eksistensi sumber daya manusia dalam organisasi sangat kuat. Guna mencapai kondisi yang lebih baik, maka dituntut adanya Manajemen terhadap sumber daya manusia secara memadai sehingga terciptalah sumber daya manusia yang berkualitas, loyal dan berprestasi.

Manajemen sumber daya manusia merupakan usaha untuk mengerahkan dan mengelola sumber daya manusia di dalam organisasi agar mampu berpikir dan bertindak sebagaimana yang diinginkan oleh organisasi. Motivasi atau dorongan karyawan dalam menjalankan kewajibannya menjadi pertaruhan yang juga sangat penting dalam sebuah organisasi. Motivasi menggambarkan keinginan pribadi karyawan untuk bekerja dengan sungguhsungguh. Hubungan motivasi dengan kinerja, sebagaimana yang dikemukakan oleh Gibson, Ivancevich dan Donnely (2012) dalam kesimpulannya tentang motivasi mengemukakan bahwa motivasi terkait erat dengan 
perilaku dan prestasi kerja. Selain itu, dinyatakan bahwa motivasi dilakukan untuk mencapai suatu tujuan tertentu. Motivasi diduga kuat berhubungan erat dengan kinerja. Motivasi diberikan kepada pegawai agar pegawai mengerahkan seluruh kemampuan, tenaga dan waktunya untuk menyelenggarakan kegiatan-kegiatan dan menunaikan kewajiban dalam rangka mencapai tujuan dan sasaran organisasi.

Stolovitch and Keeps dalam Veithzal Rivai Ahmad Fawzi (2012), kinerja merupakan seperangkat hasil yang dicapai dan merujuk pada tindakan pencapaian serta pelaksanaan sesuatu pekerjaan yang diminta. Bernadian dalam Sedarmayanti (2012) kinerja didefinisikan sebagai catatan mengenai outcome yang dihasilkan dari suatu aktivitas tertentu, selama kurun waktu tertentu pula. W.F. Cascio dalam Robbins (2012), kinerja adalah suatu hal yang sangat penting karena dapat digunakan sebagai masukan untuk membuat keputusan.

Disiplin kerja merupakan bagian dari ketaatan karyawan pada semua peraturan yang ditetapkan oleh perusahaan. Perilaku karyawan dapat dikendalikan atau tidak, tercermin dari serangkaian tingkah laku taat tidaknya pada peraturan. Pegawai atau karyawan yang tidak mentaati peraturan jelas merupakan perilaku yang kurang baik dan harus segera diberikan arahan agar dapat berubah. Bentuk arahan dapat saja dengan cara teguran, surat peringatan. Penerapan disiplin dalam bekerja menjadi penting mengingat disiplin kerja akan memiliki pengaruh pada kinerja perusahaan. Pendapat Edwin Locke dalam Robbins (2012) mengemukakan niat-niat untuk bekerja menuju sasaran merupakan sumber utama dari motivasi kerja. Artinya sasaran sebagai acuan karyawan tentang apa yang akan dikerjakan dan berapa banyak upaya yang akan dilakukan. Semakin para pegawai termotivasi dalam bekerja, maka para pegawai bekerja dengan rasa tenang, dan yang lebih penting lagi kepuasan kerja yang tinggi akan memperbesar kemungkinan tercapainya motivasi yang tinggi dan kinerja yang tinggi pula. Dengan demikian semua tahapan dapat dijalankan dengan sebaikbaiknya.

Karyawan yang merasa tidak puas terhadap pekerjaannya, cenderung akan melakukan penarikan atau penghindaran diri dari situasisituasi pekerjaan baik yang bersifat fisik maupun psikologis menurut Early dalam Robbins (2012). Bila seseorang termotivasi, ia akan berusaha berbuat sekuat tenaga untuk mewujudkan apa yang diinginkannya. Namun belum tentu upaya yang keras itu akan menghasilkan kinerja yang diharapkan, apabila tidak disalurkan dalam arahan seorang pimpinan untuk mencapai tujuan organisasi. Oleh karenaitu, upaya tersebut di atas diarahkan dan lebih konsisten dengan tujuan ke dalam sasaran organisasi. Organisasi juga dituntut mampu mengidentifikasikan kemauan para anggotanya yang menimbulkan kepuasan kerja melalui berbagai cara dengan memenuhi kebutuhan anggota organisasi, baik yang bersifat motivator sebagai faktor intrinsik maupun hygiene sebagai faktor ekstrinsik.

Suatu kebutuhan yang tidak terpuaskan akan menciptakan tegangan yang merangsang dorongan-dorongan di dalam diri individu. Dorongan ini menimbulkan suatu perilaku pencarian untuk menemukan tujuan-tujuan tertentu yang apabila tercapai akan memenuhi kebutuhan itu dan mendorong ke pengurangan tegangan. Oleh karena itu, melekat di dalam definisi motivasi adalah bahwa kebutuhan individu itu sesuai dan konsisten dengan tujuan dan sasaran organisasi. Apabila nilai ini tidak terjadi, maka akan terwakili individu-individu yang mengeluarkan tingkat biaya tinggi, yang sebenarnya berlawanan dengan kepentingan organisasi. Rendahnya kinerja dan motivasi karyawan yang dihadapi sebenarnya merupakan permasalahan klasik namun selalu up to date untuk didiskusikan. Sumber daya manusia adalah potensi yang merupakan aset dan berfungsi sebagai modal di dalam organisasi.

Motivasi kerja merupakan faktor yang juga dibahas dalam penelitian ini, berhubungan 
dengan tingginya kinerja organisasi. Dengan kata lain, makin tinggi motivasi kerja dan komitmen, maka makin tinggi pula kinerja yang dihasilkan pegawai tersebut, sehingga pada akhirnya pegawai mau dan ikhlas bekerja dengan sebaik mungkin demi tercapainya tujuan organisasi dan berbagai sasarannya.

Tujuan penetapan indikator kinerja utama di lingkungan Kantor Bank BRI Cabang Pamulang diantaranya untuk memperoleh informasi kinerja yang penting dan diperlukan dalam menyelenggarakan manajemen kinerja secara baik; untuk memperoleh ukuran keberhasilan dari pencapaian suatu tujuan dan sasaran strategis yang digunakan untuk perbaikan kinerja dan peningkatan akuntabilitas kinerja dan melakukan evaluasi dari setiap indikator yang menjadi tolok ukur kinerjanya.

Peningkatan kinerja di sisi lain tidak bisa dilakukan tanpa adanya manajemen yang baik. Manajemen tersebut harus merupakan suatu siklus tahapan-tahapan perencanaan, pelaksanaan, pemantauan dan evaluasi. Hasil evaluasi kinerja menjadi feedback bagi tahapan perencanaan berikutnya. Dengan demikian, manajemen kinerja diperlukan agar upayaupaya peningkatan kinerja tertata dengan baik dalam siklus tahapan kerja yang tidak terputus, sehingga terbangun budaya kerja yang berorientasi pada proses dan hasil optimal.

Setiap organisasi mengharapkan agar pegawainya dapat berkinerja dengan baik. Informasi mengenai kinerja pegawai diperoleh melalui penilaian kinerja. Dari hasil evaluasi kinerja pegawai dapat diketahui apakah seorang pegawai dapat bekerja dengan baik atau tidak yang dilihat dari kategori penilaian yang dibandingkan antara tolok ukur penilaian kinerja organisasi dengan kinerja pegawai. Sehingga dapat diartikan bahwa penilaian yang semakin tinggi menjadi indikasi bahwa kinerja pegawai tersebut mampu memenuhi harapan kinerja organisasi.

Hasil evaluasi kinerja menjadi feedback bagi tahapan perencanaan berikutnya. Dengan demikian, manajemen kinerja diperlukan agar upaya-upaya peningkatan kinerja tertata dengan baik dalam siklus tahapan kerja yang tidak terputus, sehingga terbangun komitmen organisasi yang berorientasi pada proses dan hasil yang optimal. Dalam kinerjanya semua elemen yang ada didalam organisasi memiliki kewajiban mewujudkan visi dan misi yang berkaitan dengan pandangan ke depan menyangkut visi yang ditanamkan pada setiap unsur organisasi akan menjadi visi bersama (shared vision) yang mampu mengarahkan dan menggerakkan segala sumber daya instansi serta sesuatu yang baru diemban atau dilaksanakan oleh seluruh karyawan. Dengan pernyataan misi diharapkan seluruh anggota organisasi dan pihak yang berkepentingan dapat mengetahui dan mengenal keberadaan dan peran organisasi dalam pelayanan masyarakat perbankan.

Berdasarkan pengamatan atau pra riset yang penulis lakukan terhadap kinerja karyawan di Bank BRI Cabang Pamulang, terlihat bahwa kinerja karyawan masih belum optimal terbukti masih banyaknya karyawan dengan tingkat kehadiran yang rendah, penyelesaian pekerjaan yang tidak sesuai dengan target yang diinginkan, pelayanan yang lambat, dan kedisiplinan yang rendah.

Kondisi-kondisi tersebut perlu mendapatkan perhatian pimpinan agar kinerja karyawan menjadi lebih baik dimasa yang akan datang. Hal yang mendasar yang harus dilakukan oleh pimpinan adalah perlunya menerapkan kedisiplinan menyeluruh mulai dari tingkat bawah sampai pada pimpinan sehingga komponen yang dinilai mampu memberikan kriteria sangat baik, hal ini akan terlihat pada nilai target dan realisasi hasil kerja dimana hasil penilaian masing-masing komponen kinerja karyawan secara umum agar menjadi lebih baik.

Penilaian evaluasi kinerja merupakan salah satu upaya untuk mengetahui kondisi motivasi dan pencapaian kerja, sehingga dapat diketahui dengan pasti apakah pencapaian 
hasil, kemajuan dan kendala yang dijumpai dalam pelaksanaan program dan kegiatan dapat dinilai dan dipelajari untuk perbaikan di masa mendatang. Di sisi lain, evaluasi kinerja adalah aktivitas pemberian nilai, apresiasi dan pengenalan permasalahan, serta pemberian solusi atas masalah yang ditemukan untuk tujuan peningkatan kinerja dan akuntabilitas unit kerja di Bank BRI Cabang Pamulang.

Dalam berbagai hal, evaluasi dilakukan melalui monitoring terhadap sistem yang ada. Namun, adakalanya evaluasi tidak dapat dilakukan hanya dengan menggunakan informasi yang dihasilkan oleh sistem informasi yang ada pada unit kerja. Data dari luar unit kerja juga sangat penting sebagai bahan analisis yang dapat dipakai dalam mengukur kinerja karyawan.

Mengingat bahwa disiplin kerja dan motivasi merupakan faktor yang dapat memberikan kinerja karyawan, maka penulis tertarik untuk melakukan penelitian lebih dalam dengan judul "Pengaruh Disiplin Kerja Dan Motivasi Terhadap Kinerja Karyawan Pada PT. Bank Rakyat Indonesia Cabang Pamulang”.

\section{PEMBATASAN MASALAH}

Dengan keterbatasan peneliti serta agar lebih mudah dipahami dan dimengerti maka penelitian ini penulis memberikan batasanbatasan yang diteliti, yaitu mengenai disiplin kerja dan motivasi dan pengaruhnya terhadap kinerja karyawan di PT. Bank Rakyat Indonesia Cabang Pamulang, dengan cara melakukan penyebaran kuesioner kepada karyawan.

\section{PERUMUSAN MASALAH}

Berdasarkan identifikasi dan pembatasan masalah di atas, maka untuk mencegah terjadinya kerancuan dalam pembahasan, perlu penulis berikan suatu perumusan masalah sebagai berikut :

1. Apakah terdapat pengaruh secara parsial antara disiplin kerja terhadap kinerja karyawan pada PT. Bank Rakyat Indonesia

\section{Cabang Pamulang.}

2. Apakah terdapat pengaruh secara parsial antara motivasi terhadap kinerja karyawan pada PT. Bank Rakyat Indonesia Cabang Pamulang.

3. Apakah terdapat pengaruh antara disiplin kerja dan motivasi secara bersama-sama terhadap kinerja karyawan pada PT. Bank Rakyat Indonesia Cabang Pamulang.

\section{TUJUAN PENELITIAN}

Tujuan penelitian ini adalah :

1. Untuk mengetahui seberapa besar pengaruh secara parsial antara disiplin kerja terhadap kinerja karyawan pada PT. Bank Rakyat Indonesia Cabang Pamulang.

2. Untuk mengetahui seberapa besar pengaruh secara parsial antara motivasi terhadap kinerja karyawan pada PT. Bank Rakyat Indonesia Cabang Pamulang.

3. Untuk mengetahui seberapa besar pengaruh secara simultan antara disiplin kerja dan motivasi terhadap kinerja karyawan pada PT. Bank Rakyat Indonesia Cabang Pamulang.

\section{TINJAUAN TEORITIK}

\section{Manajemen Sumber Daya Manusia}

Dalam suatu organisasi atau perusahaan perannan manajemen sumber daya manusia sangatlah penting.Hal ini dapat kita mengerti karena tanpa sumber daya manusia, suatu organisasi tidak mungkin berjalan. Manusia merupakan penggerak dan pengelola faktorfaktor produksi lainnya seperti modal, bahan mentah, peralatan, dan lain-lain untuk mencapai tujuan organisasi.

Menurut Edi Sutrisno (2011) menyatakan bahwa "Manajemen sumber daya manusia merupakan suatu kebijakan dan praktik yang dibutuhkan seseorang yang menjalankan aspek "orang" atau sumber daya manusia dari posisi seorang manajemen, meliputi perekrutan, penyaringan, pelatihan, pengimbalan, dan penilaian". Sedangkan menurut Marwansyah 
(2012) menjelaskan "Manajemen sumber daya manusia merupakan proses perencanaan, pengorganisasian, pengarahan, dan pengawasan atas fungsi pengadaan, pengembangan, pemberian balas jasa, integrasi, pemeliharaan, dan pemutusan hubungan kerja agar tujuantujuan individu, organisasi, dan masyarakat dapat dicapai". Lain halnya dengan pendapat Mathis dan Jackson (2012) yang mengemukakan "Rancangan sistem-sistem formal dalam sebuah organisasi untuk memastikan penggunaan bakat manusia secara efektif dan efisien guna mencapai tujuan organisasi".

Dari beberapa pendapat ahli tersebut dapat disimpulkan bahwa manajemen sumber daya manusia adalah aktivitas yang dilakukan dengan mendayagunakan manusia untuk menunjang tercapainya tujuan organisasi itu sendiri. Fokus utama manajemen sumber daya manusia adalah pengelolaan pegawai, yaitu mengarahkan perilaku pegawai bagi kepentingan perusahaan atau instansi.

\section{Sumber Daya Manusia}

Menurut Dessler Gerry (2000) yang menjadi pekerjaan dalam manajemen personalia adalah "Analisis pekerjaan, (menetapkan hakikat pekerjaan pegawai), perencanaan kebutuhan tenaga kerja dan pendaftaran calon pegawai, seleksi calon pegawai, orientasi dan pelatihan pegawai baru, manajemen upah dan gaji, (cara mengkompensasi pegawai), penyediaan insentif dan kesejahteraan, penilaian prestasi kerja, komunikasi tatap muka, (interview, penyuluhan, dan penertiban), pengembangan manajer".

Sedangkan menurut Follet dalam Sule (2005) menyatakan bahwa "Management is the art of getting things done through people (manajemen sumber daya manusia adalah seni dalam menyelesaikan sesuatu melalui orang lain)". Manajemen sumber daya manusia menerapkan manajemen berdasarkan fungsinya untuk memperoleh yang terbaik dan dapat dipelihara kualitas pekerjaannya.
Menurut Samsudin (2012) "Manajemen sumber daya manusia adalah suatu kegiatan pengelolaan yang meliputi pendayagunaan, pengembangan, penilaian, pemberian balas jasa bagi manusia sebagai individu anggota organisasi atau perusahaan bisnis". Defenisi lain manajemen sumberdaya manusia adalah suatu proses perencanaan, pengorganisasian, pengarahan dan pengendalian sumber daya manusia dalam rangka pencapaian tujuan organisasi.

Berdasarkan pendapat di atas dapat disimpulkan bahwa manajemen sumber daya manusia adalah perencanaan, pengorganisasian, pergerakan, dan pengendalian atas pengadaan tenaga kerja, pengembangan, kompensasi, integritas, pemeliharaan, pemutusan hubungan kerja dan sumber daya manusia untuk mencapai sasaran perorangan, organisasi dan masyarakat.

\section{Disiplin kerja}

Menurut Setiyawan dan Waridin (2012) adalah "Disiplin merupakan suatu bentuk ketaatan terhadap aturan, baik tertulis maupun tidak tertulis yang telah ditetapkan". Disiplin kerja pada dasarnya selalu diharapkan menjadi ciri setiap sumber daya manusia dalam organisasi, karena dengan kedisplinan organisasi akan berjalan dengan baik dan bisa mencapai tujuannya dengan baik pula.

Menurut Veithzal Rivai dan Ella Jauvani (2012) mengemukakan "Disiplin kerja adalah suatu alat yang digunakan para manajer untuk berkomunikasi dengan karyawan agar mereka bersedia untuk mengubah suatu perilaku serta sebagai suatu upaya untuk meningkatkan kesadaran dan kesediaan seseorang mentaati semua peraturan perusahaan dan norma-norma yang berlaku".

Sedangkan menurut Siagian (2012) mengemukakan bahwa "Disiplin karyawan dalam manajemen sumber daya manusia berangkat dari pandangan bahwa tidak ada manusia yang sempurna, lepas dari kesalahan dan kekhilafan". 
Dari beberapa pendapat di atas dsiplin kerja merupakan suatu bentuk upaya pegawai yang berusaha memperbaiki dan membentuk pengetahuan ,sikap dan perilaku karyawan sehingga perilaku karyawan tersebut secara sukarela berusaha bekerja secara koperatif dengan para karyawan lain serta meningkatkan prestasi kerja.

Sintesis dari disiplin kerja pada penelitian ini menurut Hasibuan (2012) berpendapat "Kedisiplinan adalah kesadaran dan kesediaan seseorang menaati semua peraturan dan peraturan-peraturan yang berlaku". Disiplin karyawan yang baik dapat mencerminkan seberapa besar tanggung jawab seorang karyawan terhadap pekerjaannya. Hal ini dapat mendorong gairah kerja sehingga tujuan organisasi dapat tercapai. Lebih lanjut Menurut Hasibuan (2012), indikator yang mempengaruhi tingkat kedisiplinan seseorang dalam suatu organisasi, diantaranya :

a. Tujuan dan kemampuan, merupakan pemahaman karyawan pada tujuan organisasi serta pemberian pekerjaan yang dibebankan kepada karyawan yang harus sesuai dengan pegawai yang bersangkutan.

b. Keteladanan pemimpin. Merupakan sikap, tingkah laku dan kinerja pimpinan yang dijadikan teladan dan panutan oleh bawahannya.

c. Balas jasa (gaji dan kesejahteraan). Mengkaji ulang gaji, kesejahteraan serta pemberian balas jasa yang dibayarkan kepada karyawan berdasarkan pekerjaan yang telah diselesaikan.

d. Keadilan dengan tidak membedakan pegawai. Kebijakan tidak terlepas dari peran kepentingan karyawan dan penegakan peraturan tidak membedakan pegawai yang satu dengan yang lain karena instansi melakukan keadilan terhadap semua pegawai.

e. Sanksi hukuman bersifat mendidik. Merupakan sanksi atas kesalahan yang diberikan dijalankan dengan baik sesuai tanpa me- mihak serta dengan ketentuan yang berlaku, hendaknya bersifat mendidik dan menjadi alat motivasi untuk memelihara kedisiplinan dalam perusahaan.

f. Ketegasan. Merupakan perlakuan yang tidak memihak serta diperlukan dalam menjaga hubungan organisasi.

Disiplin perlu untuk mengatur tindakan kelompok, dimana setiap anggotanya harus mengendalikan dorongan hatinya dan bekerja sama demi kebaikan bersama. Dengan kata lain, mereka harus secara sadar tunduk pada aturan perilaku yang diadakan oleh kepemimpinan organisasional, yang ditujukan pada tujuan yang hendak dicapai. Disiplin yang baik mencerminkan besarnya tanggung jawab seseorang terhadap tugas-tugas yang diberikan kepadanya. Hal ini mendorong gairah kerja, semangat kerja, dan terwujudnya tujuan perusahaan. Untuk mewujudkan tujuan perusahaan, harus dibangun dan ditegakkan kedisiplinan karyawan. Jadi, kedisiplinan merupakan kunci keberhasilan suatu perusahaan dalam mencapai tujuan organisasi.

\section{Motivasi}

Menurut Sarwoto (2011) secara konkrit motivasi dapat diberi batasan sebagai "Proses pemberian motif (penggerak) bekerja kepada para bawahan sedemikian rupa sehingga mereka mau bekerja dengan ikhlas demi tercapainya tujuan organisasi secara efisien. Maka Pengertian motivasi adalah pemberian atau penimbulan motif atau dapat pula diartikan sebagai hal atau keadaan menjadi motif, dan sesuatu yang menimbulkan semangat atau dorongan kerja.

Jadi motivasi adalah pemberian daya penggerak yang menciptakan kegairahan kerja seseorang agar mau bekerjasama, bekerja efektif, dan terintegrasi dengan segala daya upayanya untuk mencapai kepuasan. Menurut Fred Luthan (2009) mengemukakan definisi motivasi sebagai berikut: "Motivation is a process thats starts with a physiological or 
physiological deficiency or need that activates behavior or a drive that is aimed at goal or incentive". Ia mengemukakan proses motivasi yaitu dengan adanya kebutuhan, dorongan dan insentif. Motivasi terdiri dari tiga elemen yang saling tergantung dan interdependen sebagai berikut:

a. Kebutuhan (needs). Kebutuhan tercipta dimana terjadi keseimbangan fisiological dan psikological. Misalnya kebutuhan fisiological terjadi ketika sel tubuh memerlukan energi dan merasa lapar.

b. Dorongan (Drives) atau motif (motives). Dorongan atau motif-dua istilah yang dipakai dengan arti yang sama muncul untuk mmengankat kebutuhan. Dorongan atau motif fisiologikal dan psikologikal berorientasi pada tindakan dan menyediakan energi untuk mencapai insentif.

c. Insentif (Incentive). Insentif menurut Wirawan (2007) adalah "Apa saja yang akan menghilangkan kebutuhan dan mengurangi dorongan. Incentif akan menyeimbangkan kembali ketidakseimbangan fisiological dan psikological dan mengurangi dorongan". Makan, minum dan bertemu keluarga merupakan insentif memenuhi kebutuhan dan mengurangi dorongan.

Pengukuran Motivasi Menurut Thoha (2012) menjelaskan "Dalam melakukan pengukuran tentang motivasi kerja, yang dapat dilakukan ialah mengidentifikasi beberapa indikator motivasi kerja. Dalam penelitian ini pengukuran motivasi berdasar kepada teori isi (content theories) dari teori motivasi dua faktor Frederick Herzberg atau two factor motivation theory". Teori ini menyebutkan bahwa kepuasan pekerja selalu dihubungkan dengan isi pekerjaan (job content), dan ketidak puasan bekerja disebabkan karena hubungan pekerjaan tersebut dengan aspek-aspek sekitar yang berhubungan dengan pekerjaan.

Kepuasan dalam bekerja disebut motivator, adapun ketidakpuasan dalam bekerja disebut faktor hygiene (Thoha, 2007). Yang termasuk kedalam faktor motivator adalah: Prestasi; Pengakuan; Pekerjaan itu sendiri; Pengembangan potensi individu. Yang termasuk faktor Higyene adalah: Gaji atau Upah; Kondisi kerja; Kebijaksanaan dan Administrasi Perusahaan; Hubungan antar Pribadi; Pengembangan potensi individu. Faktor-faktor tersebutlah yang menjadi pengukuran dalam menentukan indikator penelitian pada variabel motivasi.

Indikator dan sintesis motivasi pada penelitian ini menurut David McCleland dalam Miftah Toha (2012) adalah "Seperangkat kekuatan baik yang berasal dari dalam diri maupun dari luar diri seseorang yang mendorong untuk memulai berperilaku kerja sesuai dengan format, arah, intensitas dan jangka waktu tertentu". Lebih lanjut ditegaskan bahwa indikator motivasi kerja meliputi :

a. Kebutuhan berprestasi (Need of achievement).

b. Kebutuhan untuk menguasai sesuatu (Need of power).

c. Kebutuhan berafiliasi (Need of affiliation).

\section{Kinerja karyawan}

Menurut Wibowo (2012) mengemukakan "Kinerja merupakan hasil pekerjaan yang mempunyai hubungan kuat strategis organisasi, kepuasan kenosumen dan memberikan kontribusi ekonomi”. Sedangkan menurut Ratundo dan Sacket (2012) mendefinisikan "Kinerja adalah kegiatan yang mencakup semua tindakan atau perilaku yang dikontrol oleh individu dan memberi kontribusi pada pencapaian tujuantujuan perusahaan".

Pendapat serupa juga dikemukakan oleh Hariandja (2013) yang mengemukakan "Kinerja merupakan hasil kerja yang dihasilkan oleh karyawan atau pegawai atau perilaku nyata yang ditampilkan sesuai dengan perannya dalam organisasi. Mathis (2014) berpendapat "Kinerja adalah apa yang dilakukan atau tidak dilakukan oleh karyawan".

Dari beberapa pendapat tersebut dapat 
disimpulkan bahwa kinerja merupakan proses pencapaian tujuan organisasi dan hasil dari usaha sumber daya manusia itu sendiri dalam sebuah organisasi.

Pentingnya penilaian kinerja karyawan menurut Mathis dan Jackson (2012) berpendapat "Penilaian kinerja merupakan proses mengevaluasi seberapa baik karyawan melakukan pekerjaan mereka jika dibandingkan dengan seperangkat standar, dan kemudian mengomunikasikan informasi tersebut kepada karyawan". Sedangkan menurut Thomas dan Scott (2013:28) berpendapat "Penilaian kinerja adalah penilaian dari kinerja jabatan seseorang karyawan, dimana merupakan salah satu tanggung jawab paling penting yang ada pada seorang manajer".

Menurut Elya (2010) "Penilaian kinerja berguna untuk memperbaiki kinerja di masa yang akan datang, memberikan nilai umpan balik tentang kualitas kerja untuk kemudian mempelajari kemajuan perbaikan yang dikehendaki dalam kinerja". Windy dan Gunasti (2012) berpendapat serupa bahwa "Penilaian kinerja karyawan merupakan sarana untuk memperbaiki karyawan yang tidak melakukan tugasnya dengan baik dan membuat karyawan mengetahui posisi dan perannya dalam menciptakan tercapainya tujuan perusahaan.

Dari beberapa pendapat ahli di atas disimpulkan bahwa sangat penting sebuah perusahaan melakukan penilaian kinerja karyawannya karena pada dasarnya merupakan penentuan secara periodic efektivitas operasional suatu organisasi dan personilnya berdasarkan sasaran, standar, dan kriteria yang telah ditetapkan sebelumnya.

Pengukuran kinerja pegawai perlu dilakukan untuk mengetahui apakah selama pelaksanaan kinerja terdapat deviasi dari rencana yang telah ditentukan, atau apakah kinerja dapat dilakukan sesuai jadwal waktu yang ditentukan, atau apakah hasil kinerja telah tercapai sesuai dengan yang diharapkan.

Menurut Hasibuan (2012) terdapat bebe- rapa indikator penilaian kinerja pegawai yaitu meliputi :

a. Prestasi yaitu penilaian hasil kerja baik kualitas maupun kuantitas yang dapat dihasilkan karyawan.

b. Kedisiplinan yaitu penilaian disiplin dalam mematuhi peraturan-peraturan yanng ada dan melakukan pekerjaan sesuai dengan instruksi yang diberikan kepadanya.

c. Kreatifitas yaitu penilaian kemampuan karyawan dalam mengembangkan kreatifitas untuk menyelesaikan pekerjaannya sehingga dapat bekerja lebih berdaya guna.

d. Bekerja sama yaitu penilaian kesediaan karyawan berpartisipasi dan bekerja sama dengan karyawan lain secara vertical atau horizontal di dalam maupun di luar sehingga pekerjaannya lebih baik.

e. Kecakapan yaitu penilaian dalam menyatukan bermacam-macam elemen yang terlibat dalam menyusun kebijaksanaan dan dalam situasi manajemen.

f. Tanggung jawab yaitu penilaian kesediaan karyawan/pegawai dalam mempertanggung jawabkan kebijaksanaannya, pekerjaan dan hasil kerjanya, sarana dan prasarana yang digunakan

\section{HIPOTESIS PENELITIAN}

Hipotesis menurut Sugiyono (2014) adalah jawaban sementara terhadap rumusan masalah. Karena sifatnya masih sementara, maka perlu dibuktikan kebenarannya melalui data empirik yang terkumpul.

Adapun Hipotesis yang penulis ajukan adalah sebagai berikut:

H1 : Diduga terdapat pengaruh positif dan signifikan antara disiplin kerja terhadap kinerja karyawan pada PT. Bank Rakyat Indonesia Cabang Pamulang.

H2 : Diduga terdapat pengaruh positif dan signifikan antara motivasi terhadap kinerja karyawan pada PT. Bank Rakyat Indonesia Cabang Pamulang.

H3 : Diduga terdapat pengaruh positif dan 
signifikan antara disiplin kerja dan motivasi secara bersama-sama terhadap kinerja karyawan pada PT. Bank Rakyat Indonesia Cabang Pamulang.

\section{METODOLOGI PENELITIAN TEMPAT DAN WAKTU PENELITIAN}

Penulis mengadakan penelitian pada PT. Bank Rakyat Indonesia Cabang Pamulang di Jalan Raya Siliwangi Ruko Pamulang Permai Blok SH 15/6, Pamulang Tangerang Selatan.

\section{POPULASI DAN SAMPEL}

\section{Populasi}

Populasi penelitian merupakan sekumpulan objek yang ditentukan melalui suatu kriteria tertentu yang akan dikategorikan ke dalam objek yang akan diteliti. Menurut Sugiyono (2014) mendefinisikan "Populasi adalah jumlah wilayah generalisasi yang terdiri atas obyek atau subyek yang mempunyai kualitas dan karakteristik yang ditetapkan oleh peneliti dan kemudian ditarik kesimpulannya. Adapun populasi dalam penelitian ini adalah karyawan PT.Bank Rakyat Indonesia Cabang Pamulang.

\section{Sampel}

Menurut Sugiyono (2014) yaitu "Sampel adalah jumlah dan karakteristik yang dimiliki oleh populasi tersebut". Sedangkan menurut Suharsini Arikunto (2010), berpendapat bahwa "Sampel adalah sebagian atau wakil populasi yang diteliti".

Dalam pengambilan sampel dapat menggunakan sampling jenuh dimana menurut Sugiyono (2014) berpendapat "Sampling jenuh adalah teknik penentuan sampel bila semua anggota populasi digunakan sebagai sampel". Istilah lain sampel jenuh adalah sensus, dimana anggota populasi di jadikan sebagai sampel. Dengan demikian sampel dalam penelitian ini adalah teknik sampling jenuh yaitu orang karyawan PT. Bank Rakyat Indonesia Cabang Pamulang, dalam hal ini berjumlah 60 orang.

\section{VARIABEL PENELITIAN}

Dalam penelitian ini terdapat tiga variabel, yaitu variabel independen dan variabel dependen, sebagai berikut :

1. Variabel bebas (independent variable) Variabel bebas yang dalam hubungannya dengan variabel lain bertindak sebagai penyebab atau yang mempengaruhi variabel dependen. Pada penelitian ini sebagai variabel independen yakni disiplin kerja dan motivasi. Variabel independen sering disebut sebagai predictor yang dilambangkan dengan $\mathrm{X}$.

2. Variabel terikat (dependent variable) Variabel yang tergantung dengan variabel lain, atau variabel yang dapat dipengaruhi oleh variabel lain. Sering disebut variabel respon di mana dalam penelitian ini adalah kinerja karyawan yang dilambangkan dengan $\mathrm{Y}$.

\section{DEFINISI OPERASIONAL VARIABEL}

Pengertian operasional variabel ini kemudian diuraikan menjadi indikator empiris yang meliputi :

1. Disiplin Kerja $\left(\mathrm{X}_{1}\right)$

Merupakan kesadaran dan kesediaan seseorang menaati semua peraturan dan peraturan-peraturan yang berlaku. Variabel ini diukur melalui indikator : tujuan dan kemampuan, peran keteladanan pemimpin, balas jasa, kebijakan yang adil, penerapan sanksi hukuman dan ketegasan yang tidak memihak.

2. Motivasi $\left(\mathrm{X}_{2}\right)$

Merupakan seperangkat kekuatan baik yang berasal dari dalam maupun dari luar diri seseorang yang mendorong untuk memulai berperilaku sesuai dengan format, arah, intensitas dan jangka waktu tertentu. Variabel ini diukur melalui indikator : Kebutuhan untuk berprestasi (Need of achievement), Kebutuhan untuk berkuasa (Need of power) dan Kebutuhan untuk berafiliasi (Need of affiliation). 
3. Kinerja Karyawan (Y)

Merupakan hasil kerja yang dicapai setiap karyawan sehingga dapat memberikan kontribusi positif terhadap perusahaan/ organisasi. Variabel ini diukur melalui indikator : Prestasi kerja, Kedisiplinan, Kreativitas, Kerjasama dalam bekerja dan Memiliki rasa tanggung jawab.

\section{METODE PENGUMPULAN DATA}

\section{Kuesioner}

Dalam penelitian ini untuk mendapatkan data primer kuantitatif, penulis menghubungi responden yaitu karyawan PT. Bank Rakyat Indonesia Cabang Pamulang.

\section{Wawancara}

Dalam penelitian ini untuk mendapatkan data primer kualitatif dengan metode wawancara, penulis datang ke kantor PT. Bank Rakyat Indonesia Cabang Pamulang untuk melakukan studi pendahuluan dengan teknik wawancara langsung dengan pihak yang berkompeten dalam perusahaan, mengenai obyek yang diteliti.

\section{Studi Pustaka}

Untuk medapatkan data sekunder penulis melakukan dengan cara penelaahan terhadap literatur-literatur berupa buku-buku kuliah dan data yang diperoleh dalam bentuk yang sudah jadi, sudah diolah oleh pihak lain biasanya dalam bentuk publikasi serta bahan-bahan yang berhubungan dengan masalah yang berkaitan dengan penelitian ini.

\section{METODE ANALISIS DATA}

Metode analisis data yang digunakan dalam penelitan ini adalah:

\section{Uji Validitas}

Untuk mengolah uji validitas, penulis menggunakan korelasi Product Moment yaitu dengan mengkorelasikan skor item dengan skor total sehingga diperoleh nilai $\mathrm{r}_{\text {hitung }}$ kemudian dibandingkan dengan $r_{\text {tabel }}$. Jika nilai $r_{\text {hitung }}$ lebih besar dari $\mathrm{r}_{\text {tabel }}$ dan nilai $\mathrm{r}$ positif, maka butir pernyataan dikatakan valid. Begitu juga sebaliknya, jika $\mathrm{r}_{\text {hitung }}$ lebih kecil atau kurang dari $\mathbf{r}_{\text {table, }}$, maka data tersebut tidak valid Nilai $\mathrm{r}_{\text {tabel }}$ untuk 60 responden dengan taraf kesalahan $5 \%$ sebesar nilai $r_{\text {tabel }}$ nya adalah sebesar 0,254 .

\section{Uji Reliabilitas}

Model analisis uji reliabiltas yang digunakan dalam penelitian ini adalah model Alpha Cronbach.

Menurut Arief (2009:317) untuk menentukan reliabel tidaknya sebuah instrumen dilakukan dengan cara membandingkan antara nilai $\mathrm{r}_{\text {Alpha }}$ (Alpha Cronbach) dengan rtable yang sudah di ketahui pada uji validitas. Adapun kriteria reliabilitas dalam penelitian ini adalah:

- Jika $\mathrm{r}_{\text {Alpha }}$ positif dan lebih besar dari $\mathrm{r}_{\text {table }}$ maka instrumen tersebut dinyatakan handal (reliable).

- Sebaliknya jika $\mathrm{r}_{\text {Alpha }}$ negatif atau $\mathrm{r}_{\text {Alpha }}$ kurang dari $\mathrm{r}_{\text {table }}$, maka instrumen tersebut dinyatakan tidak handal (not reliable).

\section{Analisis Regresi Lnier Sederhana}

Analisis regresi liner sederhana ini dalam penelitian ini dimaksudkan untuk menganalisis pengaruh secara parsial antara variabel disiplin kerja $\left(\mathrm{X}_{1}\right)$ dan motivasi $\left(\mathrm{X}_{2}\right)$ terhadap kinerja karyawan $(\mathrm{Y})$.

\section{Analisis Regresi Berganda}

Di mana untuk mencapai tujuan penelitian yaitu menganalisis pengaruh disiplin kerja $\left(\mathrm{X}_{1}\right)$ dan motivasi $\left(\mathrm{X}_{2}\right)$ secara bersamasama terhadap kinerja karyawan (Y) adalah dengan menggunakan analisis regresi berganda (Multiple regresional analisis).

\section{Analisis Koefisien Determinasi}

Dalam penelitian ini untuk mengetahui berapa besar prosentase kontribusi dari variabel disiplin kerja dan motivasi terhadap kinerja karyawan pada PT. Bank Rakyat Indonesia Cabang Pamulang baik secara parsial maupun 
secara simultan.

\section{Uji Hipotesis}

Pengujian hipotesis dimaksudkan untuk menguji dugaan sementara yang dirumuskan dalam hipotesis berdasarkan data empiris. Dalam penelitian ini pengujian hipotesis dilakukan dengan uji t dan uji $\mathrm{F}$.

\section{a. Uji t}

Uji t digunakan untuk menguji signifikansi variasi hubungan antar variabel $\mathrm{X}$ dan Y. Dalam penelitian ini untuk menguji apakah variabel $\mathrm{X}_{1}$ dan $\mathrm{X}_{2}$ secara parsial benar-benar berpengaruh secara parsial terhadap variabel dependen.

b. Uji F

Pengujian hipotesis simultan (Uji F) bertujuan untuk mengetahui pengaruh secara bersama-sama variabel independen terhadap variabel dependen. Dalam penelitian ini untuk menguji apakah variabel $\mathrm{X}_{1}$ dan $\mathrm{X}_{2}$ secara bersama-sama benar-benar berpengaruh secara parsial terhadap variabel dependen.

\section{ANALISIS DAN PEMBAHASAN ANALISIS DESKRIPTIF VARIABEL PENELITIAN}

Sesuai dengan tujuan analisis deskriptif yaitu untuk memberikan gambaran mengenai hasil penelitian secara umum, bagaimana karakteristik subyek penelitian sehubungan dengan variabel-variabel yang diteliti. Sebelum dilakukan analisis statistik terlebih dahulu dilakukan pembobotan terhadap skor masingmasing variabel. Pembobotan dilakukan dengan memberikan skor total dengan jumlah item dari variabel yang dibobot, melalui pertanyaaan yang diberikan penulis dalam kuesioner dapat di deskriptifkan setiap variabel yang diteliti.

Metode yang diambil dalam penelitian ini adalah metode pengukuran Likert. Dimana pertanyaan mengandung lima alternatif jawaban. Dan bentuk pertanyaan telah disusun menggunakan pengukuran Likert yang diberi bobot sebagai berikut:

Tabel 1 Skala Likert

\begin{tabular}{|c|c|}
\hline Jawaban & Bobot \\
\hline Sangat Setuju (SS) & 5 \\
\hline Setuju (S) & 4 \\
\hline Kurang Setuju (KS) & 3 \\
\hline Tidak Setuju (TS) & 2 \\
\hline Sangat Tidak Setuju (STS) & 1 \\
\hline
\end{tabular}

Sugiyono (2014)

\section{Range Kelas}

$$
\mathrm{P}=\frac{\text { Range }}{\text { Kelas }}=\frac{5-1}{5}=0,8
$$

Maka dapat ditetapkan interval sebagai berikut :

Tabel 2 Rentang Skala

\begin{tabular}{|c|c|}
\hline $\begin{array}{c}\text { Nilai } \\
\text { Rata-rata }\end{array}$ & Bobot \\
\hline $1,00-1,79$ & Sangat Tidak Setuju (STS) \\
\hline $1,80-2,59$ & Tidak Setuju (TS) \\
\hline $2,60-3,39$ & Kurang Setuju (KS) \\
\hline $3,40-4,19$ & Setuju (S) \\
\hline $4,20-5,00$ & Sangat Setuju (SS) \\
\hline
\end{tabular}

Sumber : Sugiyono (2014)

\section{Variabel Disiplin kerja $\left(\mathrm{X}_{1}\right)$}

Disiplin kerja adalah kesadaran dan kesediaan seseorang menaati semua peraturan dan peraturan-peraturan yang berlaku. Variabel ini diukur melalui indikator : tujuan dan kemampuan, peran keteladanan pemimpin, balas jasa, kebijakan yang adil, penerapan sanksi hukuman dan ketegasan yang tidak memihak. Adapun penilaian responden atas disiplin kerja yang dilakukan PT. Bank Rakyat Indonesia Cabang Pamulang dapat di paparkan sebagai berikut: 
Tabel 3 Variabel Disiplin Kerja $\left(\mathrm{X}_{1}\right)$

\begin{tabular}{|c|c|c|c|c|c|c|c|c|c|}
\hline \multirow{2}{*}{ No } & \multirow{2}{*}{ Pernyataan } & STS & TS & KS & $\mathbf{S}$ & SS & \multirow{2}{*}{ Total } & \multirow{2}{*}{$\begin{array}{l}\text { Rata- } \\
\text { rata }\end{array}$} & \multirow{2}{*}{ Ket } \\
\hline & & (1) & (2) & (3) & (4) & (5) & & & \\
\hline 1. & Tujuan jelas & 0 & 2 & 18 & 27 & 13 & 60 & 3.85 & $\mathrm{~S}$ \\
\hline 2. & Sesuai kemampuan & 0 & 2 & 18 & 30 & 10 & 60 & 3.80 & $\mathrm{~S}$ \\
\hline 3. & Keteladanan pimpinan & 0 & 2 & 20 & 30 & 8 & 60 & 3.73 & $\mathrm{~S}$ \\
\hline 4. & Pimpinan yang baik & 0 & 2 & 17 & 25 & 16 & 60 & 3.92 & $\mathrm{~S}$ \\
\hline 5. & Gaji dan kesejahteraan & 0 & 1 & 16 & 28 & 15 & 60 & 3.95 & $\mathrm{~S}$ \\
\hline 6 & Sesuai beban kerja & 0 & 1 & 17 & 32 & 10 & 60 & 3.85 & $\mathrm{~S}$ \\
\hline 7 & Kebijakan yang adil & 0 & 2 & 17 & 28 & 13 & 60 & 3.87 & $\mathrm{~S}$ \\
\hline 8 & Kebijakan tidak memihak & 0 & 1 & 17 & 28 & 14 & 60 & 3.92 & $\mathrm{~S}$ \\
\hline 9 & Penerapan sanksi esuai & 0 & 1 & 19 & 28 & 12 & 60 & 3.85 & $\mathrm{~S}$ \\
\hline 10 & Pemberian hukuman & 0 & 1 & 26 & 24 & 9 & 60 & 3.68 & $\mathrm{~S}$ \\
\hline 11 & Tegas tidak memihak & 1 & 1 & 11 & 30 & 17 & 60 & 4.02 & $\mathrm{~S}$ \\
\hline \multirow[t]{2}{*}{12} & Hubungan baik & 0 & 1 & 13 & 33 & 13 & 60 & 3.97 & $\mathrm{~S}$ \\
\hline & \multicolumn{7}{|c|}{ Rata-rata Variabel Disiplin Kerja } & 3.97 & $\mathrm{~S}$ \\
\hline
\end{tabular}

Sumber : Hasil Pengolahan Data Primer

Bila dilihat dari tabel di atas rata-rata skor variabel disiplin kerja sebesar 3,97 masuk pada interval 3,40 - 4,19 atau dengan interpretasi setuju. Untuk lebih baik lagi perusahaan perlu secara berkala mereview pengambilan kebijakan dengan mempertimbangkan kepentingan karyawan sehingga dapat menambah semangat kerja yang ada pada pribadi karyawan.

\section{Variabel Motivasi $\left(\mathrm{X}_{2}\right)$}

Motivasi adalah seperangkat kekuatan baik yang berasal dari dalam maupun dari luar diri seseorang yang mendorong untuk memulai berperilaku sesuai dengan format, arah, intensitas dan jangka waktu tertentu. Variabel ini diukur melalui indikator : Kebutuhan berprestasi (Need of achievement), Kebutuhan untuk menguasai sesuatu (Need of power), Kebutuhan berafiliasi (Need of affiliation). Adapun penilaian responden atas motivasi yang dilaksanakan pada PT. Bank Rakyat Indonesia Cabang Pamulang dapat di paparkan sebagai berikut:

Tabel 4 Variabel Motivasi (X)

\begin{tabular}{|c|c|c|c|c|c|c|c|c|c|}
\hline \multirow{2}{*}{ No } & \multirow{2}{*}{ Pernyataan } & STS & TS & KS & $\mathbf{s}$ & SS & \multirow{2}{*}{ Total } & \multirow{2}{*}{$\begin{array}{l}\text { Rata- } \\
\text { rata }\end{array}$} & \multirow{2}{*}{ Ket } \\
\hline & & (1) & (2) & (3) & (4) & (5) & & & \\
\hline 1. & Tantangan pekerjaan & 0 & 1 & 17 & 32 & 10 & 60 & 3.85 & $\mathrm{~S}$ \\
\hline 2. & Tanggung jawab & 0 & 0 & 23 & 24 & 13 & 60 & 3.83 & $\mathrm{~S}$ \\
\hline 3. & Penghargaan prestasi & 0 & 1 & 22 & 24 & 13 & 60 & 3.82 & $\mathrm{~S}$ \\
\hline 4. & Aktualisasi dalam bekerja & 0 & 3 & 16 & 26 & 15 & 60 & 3.88 & $\mathrm{~S}$ \\
\hline 5. & Pemberian reward & 0 & 1 & 26 & 23 & 10 & 60 & 3.70 & $\mathrm{~S}$ \\
\hline 6 & Menyukai perkerjaan & 0 & 0 & 15 & 34 & 11 & 60 & 3.93 & $\mathrm{~S}$ \\
\hline 7 & Mencari kesempatan karir & 0 & 0 & 23 & 24 & 13 & 60 & 3.83 & $\mathrm{~S}$ \\
\hline 8 & Aktif dalam kegiatan & 0 & 0 & 24 & 25 & 11 & 60 & 3.78 & $\mathrm{~S}$ \\
\hline 9 & Hasrat menjadi pemimpin & 0 & 4 & 19 & 26 & 11 & 60 & 3.73 & $\mathrm{~S}$ \\
\hline 10 & Hubungan organisasi & 0 & 1 & 20 & 30 & 9 & 60 & 3.78 & $\mathrm{~S}$ \\
\hline 11 & Kerjasama antar divisi & 0 & 1 & 23 & 25 & 11 & 60 & 3.77 & $S$ \\
\hline \multirow[t]{2}{*}{12} & Menghindari konflik & 0 & 0 & 12 & 23 & 25 & 60 & 4.22 & $\mathrm{~S}$ \\
\hline & \multicolumn{7}{|c|}{ Rata-rata Variabel Motivasi } & 3.84 & S \\
\hline
\end{tabular}

Sumber : Hasil Pengolahan Data Primer 
Berdasarkan data pada tabel di atas ratarata skor variabel disiplin kerja sebesar 3,84 masuk pada interval 3,40 - 4,19 atau dengan interpretasi setuju. Untuk lebih baik lagi perusahaan perlu pemberian tanggung jawab yang lebih jelas yang disesuaikan dengan tingkat kemampuan pegawai atau karyawannya serta pentingnya memberikan reward bagi pegawai yang memiliki prestasi dalam melaksanakan tugas pekerjaannya.

\section{Variabel Kinerja Karyawan (Y)}

Kinerja karyawan adalah hasil kerja yang dicapai setiap karyawan sehingga dapat memberikan kontribusi positif terhadap perusahaan/instansi. Variabel ini diukur melalui indikator:

Prestasi kerja, Kedisiplinan dalam mematuhi peraturan, Kreatifitas karyawan, Bekerja sama, Tanggung jawab. Adapun penilaian responden atas motivasi pada PT. Bank Rakyat Indonesia Cabang Pamulang dapat di paparkan sebagai berikut:
Bila dilihat dari tabel di atas rata-rata skor variabel disiplin kerja sebesar 3,90 masuk pada interval 3,40 - 4,19 atau dengan interpretasi setuju. Untuk lebih baik lagi perusahaan perlu menanamkan pengertian akan pentingnya seluruh karyawan memiliki disiplin yang tinggi, berlomba-lomba berkompetisi secara sehat untuk mencapai prestasi kerja yang optimal.

\section{PENGUJIAN INSTRUMEN DATA}

\section{Hasil Uji Validitas}

Berdasar perhitungan dengan menggunakan menggunakan Software IBM SPSS (Statistical Program for Social Science) versi 22.00 for windows. Seluruh butir pernyataan yang digunakan dalam penelitian diperoleh nilai $\mathrm{r}_{\text {hitung }}$ lebih besar dari $\mathrm{r}_{\text {tabel }}$ dan nilai $\mathrm{r}$ positif, dengan demikian maka semua butir pernyataan dikatakan valid.

\section{Hasil Uji Reliabilitas}

Berdasar perhitungan dengan menggunakan menggunakan Software IBM SPSS (Statistical Program for Social Science) versi

Tabel 5 Variabel Kinerja Karyawan (Y)

\begin{tabular}{|c|c|c|c|c|c|c|c|c|c|}
\hline \multirow{2}{*}{ No } & \multirow{2}{*}{ Pernyataan } & STS & TS & KS & $\mathbf{S}$ & SS & \multirow{2}{*}{ Total } & \multirow{2}{*}{ Rata-rata } & \multirow{2}{*}{ Ket. } \\
\hline & & (1) & (2) & (3) & (4) & (5) & & & \\
\hline 1. & Performa pekerjaan & 0 & 0 & 14 & 37 & 9 & 60 & 3.92 & S \\
\hline 2. & Memiliki prestasi yang baik & 0 & 1 & 17 & 28 & 14 & 60 & 3.92 & S \\
\hline 3. & Peluang jabatan lebih tinggi & 0 & 0 & 22 & 29 & 9 & 60 & 3.78 & S \\
\hline 4. & Mematuhi peraturan ada & 0 & 1 & 10 & 32 & 17 & 60 & 4.08 & S \\
\hline 5. & Penegakan praturan & 0 & 1 & 26 & 23 & 10 & 60 & 3.70 & $S$ \\
\hline 6 & Disiplin membuat nyaman & 0 & 0 & 18 & 34 & 8 & 60 & 3.83 & S \\
\hline 7 & Memiliki kemampuan & 0 & 1 & 13 & 29 & 17 & 60 & 4.03 & $\mathrm{~S}$ \\
\hline 8 & Menciptakan kreativitas & 0 & 0 & 21 & 24 & 15 & 60 & 3.90 & S \\
\hline 9 & Partisipasi lingkungan kerja & 0 & 0 & 18 & 32 & 10 & 60 & 3.87 & $\mathrm{~S}$ \\
\hline 10 & Kerjasama antar rekan & 0 & 0 & 15 & 33 & 12 & 60 & 3.95 & $\mathrm{~S}$ \\
\hline 11 & Kebijaksanaan pekerjaan & 0 & 0 & 15 & 29 & 16 & 60 & 4.02 & $\mathrm{~S}$ \\
\hline \multirow[t]{2}{*}{12} & Hasil kerja yang optimal & 0 & 0 & 15 & 30 & 15 & 60 & 4.00 & $\mathrm{~S}$ \\
\hline & \multicolumn{7}{|c|}{ Rata-rata Variabel Kinerja Karyawan } & 3.90 & $S$ \\
\hline
\end{tabular}

Sumber : Hasil Pengolahan Data Primer 
22.00 for windows. Diperoleh nilai Cronbach Alfa lebih besar dari nilai $\mathrm{r}_{\text {tabel }}$ atau nilai $\mathrm{r}_{\text {hitung }}>$ $\mathrm{r}_{\text {tabel }}$ dan nilai $\mathrm{r}$ bernilai positif, dengan demikian maka butir pernyataan dalam variabel dalam penelitian dikatakan reliabel dan data layak untuk diolah ke pengujian berikutnya.

\section{HASIL ANALISIS DATA}

Pada bagian pengujian ini dimaksudkan untuk menunjukkan hasil dari pengujian atas variabel Disiplin kerja $\left(\mathrm{X}_{1}\right)$ dan Motivasi $\left(\mathrm{X}_{2}\right)$ Terhadap Kinerja Karyawan (Y). Adapun hasil analisis dalam penelitian ini sebagai berikut:

\section{Analisis Regresi Linier Sederhana}

Uji regresi linier sederhana bertujuan untuk mengetahui seberapa besar pengaruh dari variabel disiplin kerja $\left(\mathrm{X}_{1}\right)$ dan motivasi $\left(\mathrm{X}_{2}\right.$ terhadap kinerja karyawan $(\mathrm{Y})$ secara sendirisendiri. Adapun hasil analisis regresi linier sederhana sebagai berikut.

Berdasarkan perhitungan regresi linier sederhana menggunakan program IBM SPSS (Statistical Program for Social Science) versi 22.00 for windows, diperoleh hasil sebagai berikut :

Tabel 6 Hasil Uji Regresi Linier Sederhana Antara Disiplin Kerja $\left(\mathrm{X}_{1}\right)$ Terhadap Kinerja Karyawan (Y)

Coefficients $^{a}$

\begin{tabular}{|c|c|c|c|c|c|c|}
\hline & \multirow{2}{*}{ Model } & \multicolumn{2}{|c|}{$\begin{array}{l}\text { Unstandardized } \\
\text { Coefficients }\end{array}$} & \multirow{2}{*}{$\begin{array}{c}\text { Standardized } \\
\text { Coefficients }\end{array}$} & \multirow{2}{*}{$\mathrm{t}$} & \multirow{2}{*}{ Sig. } \\
\hline & & B & $\begin{array}{l}\text { Std. } \\
\text { Error }\end{array}$ & & & \\
\hline \multirow[t]{2}{*}{1} & (Constant) & 22.823 & 3.958 & & 5.767 & .000 \\
\hline & $\begin{array}{l}\text { Disiplin } \\
\text { Kerja }\left(X_{1}\right)\end{array}$ & .521 & .085 & .628 & 6.145 & .000 \\
\hline
\end{tabular}

Sumber : Data Primer yang telah diolah

Dari hasil perhitungan pada tabel di atas dapat disajikan ke dalam bentuk persamaan regresi standardized sebagai berikut :

$\mathrm{Y}=\mathbf{2 2 , 8 2 3}+\mathbf{0 , 5 2 1 \mathrm { X } _ { 1 }}$

Di mana :

$\mathrm{Y}=$ Kinerja karyawan

$\mathrm{X}_{1}=$ Variabel Disiplin kerja

Adapun persamaan tersebut dapat dijelas- kan sebagai berikut :

a. Konstanta sebesar 18,301, menyatakan bahwa tanpa dipengaruhi variabel disiplin kerja maka besarnya nilai kinerja karyawan sudah terbentuk sebesar 22,823.

b. Variabel disiplin kerja $\left(\mathrm{X}_{1}\right)$ berpengaruh positif terhadap kinerja karyawan (Y) dengan nilai koefisien sebesar 0,521. Yang artinya jika variabel disiplin kerja $\left(\mathrm{X}_{1}\right)$ meningkat satu satuan dengan asumsi variabel motivasi $\left(\mathrm{X}_{2}\right)$ tetap, maka kinerja karyawan akan meningkat sebesar 0,521 satuan.

Tabel 7 Hasil Uji Regresi Linier Sederhana Motivasi (X2) Terhadap Kinerja Karyawan (Y)

Coefficients $^{\mathrm{a}}$

\begin{tabular}{|c|c|c|c|c|c|c|}
\hline & \multirow{2}{*}{ Model } & \multicolumn{2}{|c|}{$\begin{array}{l}\text { Unstandardized } \\
\text { Coefficients }\end{array}$} & \multirow{2}{*}{\begin{tabular}{|c|}
$\begin{array}{c}\text { Standardized } \\
\text { Coefficients }\end{array}$ \\
Beta
\end{tabular}} & \multirow{2}{*}{$\mathrm{t}$} & \multirow{2}{*}{ Sig. } \\
\hline & & B & $\begin{array}{l}\text { Std. } \\
\text { Error }\end{array}$ & & & \\
\hline \multirow[t]{2}{*}{1} & (Constant) & 23.322 & 4.402 & & 5.298 & .000 \\
\hline & $\begin{array}{l}\text { Motivasi } \\
\left(\mathrm{X}_{2}\right)\end{array}$ & .513 & .095 & .579 & 5.407 & .000 \\
\hline
\end{tabular}

Sumber : Data Primer yang telah diolah

Dari hasil perhitungan pada tabel di atas dapat disajikan ke dalam bentuk persamaan regresi standardized sebagai berikut :

$\mathrm{Y}=22,322+0,513 \mathrm{X}_{2}$

Di mana :

$\mathrm{Y}=$ Kinerja karyawan

$\mathrm{X}_{2}=$ Variabel Motivasi

Adapun persamaan tersebut dapat dijelaskan sebagai berikut :

a. Konstanta sebesar 22,322, menyatakan bahwa tanpa dipengaruhi variabel motivasi maka besarnya nilai kinerja karyawan sudah terbentuk sebesar 22,322.

b. Variabel motivasi $\left(\mathrm{X}_{2}\right)$ berpengaruh positif terhadap kinerja karyawan (Y) dengan nilai koefisien sebesar 0,513 . Yang artinya jika variabel motivasi $\left(\mathrm{X}_{2}\right)$ meningkat satu satuan dengan asumsi variabel disiplin kerja $\left(\mathrm{X}_{1}\right)$ tetap, maka kinerja karyawan akan meningkat sebesar 0,513 satuan. 


\section{Analisis Regresi Berganda}

Analisis regresi berganda bertujuan untuk mengetahui seberapa besar pengaruh dari variabel disiplin kerja $\left(\mathrm{X}_{1}\right)$ dan motivasi $\left(\mathrm{X}_{2}\right.$ terhadap kinerja karyawan (Y). Berdasarkan perhitungan regresi berganda menggunakan program IBM SPSS (Statistical Program for Social Science) versi 22.00 for windows, diperoleh hasil sebagai berikut :

Tabel 8 Hasil Uji Regresi Berganda

\begin{tabular}{|c|c|c|c|c|c|c|}
\hline \multicolumn{7}{|c|}{ Coefficients $^{a}$} \\
\hline & \multirow{2}{*}{ Model } & \multicolumn{2}{|c|}{$\begin{array}{l}\text { Unstandardized } \\
\text { Coefficients }\end{array}$} & \multirow{2}{*}{$\begin{array}{c}\text { Standardized } \\
\text { Coefficients }\end{array}$} & \multirow{2}{*}{$\mathrm{t}$} & \multirow{2}{*}{ Sig. } \\
\hline & & B & $\begin{array}{l}\text { Std. } \\
\text { Error }\end{array}$ & & & \\
\hline \multirow[t]{3}{*}{1} & (Constant) & 16.493 & 4.362 & & 3.781 & \\
\hline & $\begin{array}{l}\text { Disiplin } \\
\text { Kerja }\left(X_{1}\right)\end{array}$ & .367 & .097 & .442 & 3.781 & \\
\hline & $\begin{array}{l}\text { Motivasi } \\
\left(\mathrm{X}_{2}\right)\end{array}$ & 292. & .104 & .330 & 2.820 & .007 \\
\hline
\end{tabular}

Sumber : Data Primer yang telah diolah

Dari hasil perhitungan pada tabel di atas dapat disajikan ke dalam bentuk persamaan regresi standardized sebagai berikut :

$\mathrm{Y}=16,493+0,367 \mathrm{X}_{1}+0,292 \mathrm{X}_{2}$

Di mana :

$\mathrm{Y}=$ Variabel Kinerja karyawan

$\mathrm{X}_{1}=$ Variabel Disiplin Kerja

$\mathrm{X}_{2}=$ Variabel Motivasi

Adapun persamaan tersebut dapat dijelaskan sebagai berikut :

a. Nilia konstanta diperoleh sebesar 16,493, menyatakan bahwa tanpa dipengaruhi oleh variabel disiplin kerja dan motivasi besarnya nilai kinerja karyawan sudah terbentuk sebesar 16,493.

b. Variabel disiplin kerja $\left(\mathrm{X}_{1}\right)$ berpengaruh positif dan signifikan terhadap kinerja karyawan (Y) dengan nilai koefisien sebesar 0,367 . Hal ini diartikan bahwa jika variabel disiplin kerja $\left(\mathrm{X}_{1}\right)$ meningkat satu satuan dengan asumsi variabel motivasi $\left(\mathrm{X}_{2}\right)$ tetap atau konstan (0), maka kinerja karyawan (Y) juga akan mengalami peningkatan 0,357 satuan. c. Variabel motivasi $\left(\mathrm{X}_{2}\right)$ berpengaruh positif dan signifikan terhadap kinerja karyawan (Y) dengan nilai koefisien sebesar 0,292. Hal ini diartikan bahwa jika variabel motivasi $\left(\mathrm{X}_{2}\right)$ meningkat satu satuan dengan asumsi variabel disiplin kerja $\left(\mathrm{X}_{1}\right)$ tetap atau konstan (0), maka kinerja karyawan (Y) juga akan mengalami peningkatan sebesar 0,292 satuan.

\section{Analisis Koefisien Korelasi (R)}

Analisis koefisien korelasi (R) dimaksudkan untuk mengetahui tingkat hubungan atau pengaruh dari variabel bebas terhadap variavel terikatnya. Dalam penelitian ini adalah variabel disiplin kerja dan motivasi baik secara parsial maupun secara bersama-sama terhadap kinerja karyawan. Adapun kriteria maupun pedoman yang dipakai adalah :

Tabel 9 Pedoman Uji Koefisien Korelasi Nilai Koefisien Korelasi $\quad$ Tingkat Hubungan

\begin{tabular}{|c|c|}
\hline $0,000-0,199$ & Sangat rendah \\
\hline $0,200-0,399$ & Rendah \\
\hline $0,400-0,599$ & Sedang \\
\hline $0,600-0,799$ & Kuat \\
\hline $0,800-1,000$ & Sangat kuat \\
\hline
\end{tabular}

Adapun hasil uji adalah sebagai berikut:

Deteminasi digunakan untuk mengetahui kontribusi besarnya pengaruh antara variabel bebas terhadap variabel terikat, dalam penelitian ini adalah variabel disiplin kerja dan motivasi baik secara parsial maupun secara bersama-sama terhadap kinerja karyawan. Adapun hasil pengolahan data dapat dijelaskan sebagai berikut :

Tabel 10. Hasil Uji Korelasi Antara Disiplin Kerja (X1) Terhadap Kinerja Karyawan (Y) Model Summary

\begin{tabular}{|l|r|r|r|c|}
\hline Model & \multicolumn{1}{|c|}{$\mathbf{R}$} & $\mathbf{R}$ Square & $\begin{array}{c}\text { Adjusted R } \\
\text { Square }\end{array}$ & $\begin{array}{c}\text { Std. Error of the } \\
\text { Estimate }\end{array}$ \\
\hline 1 & $.628^{\mathrm{a}}$ & .394 & .384 & 3.296 \\
\hline
\end{tabular}

Sumber : Data Primer yang telah diolah

Berdasarkan hasil uji pada tabel di atas 
dapat diperoleh nilai korelasi sebesar 0,628 bertanda positif. Dengan demikian sesuai dengan ketentuan yang ada variabel disiplin secara parsial memiliki tingkat hubungan atau pengaruh yang kuat terhadap kinerja karyawan.

Tabel 11 Hasil Uji Korelasi Antara Motivasi

$\left(\mathrm{X}_{1}\right)$ Terhadap Kinerja Karyawan (Y) Model Summary

\begin{tabular}{|l|r|r|r|r|}
\hline Model & R & R Square & $\begin{array}{c}\text { Adjusted R } \\
\text { Square }\end{array}$ & $\begin{array}{c}\text { Std. Error of the } \\
\text { Estimate }\end{array}$ \\
\hline 1 & $.579^{\mathrm{a}}$ & .335 & .324 & 3.453 \\
\hline
\end{tabular}

Sumber : Data Primer yang telah diolah

Berdasarkan hasil uji pada tabel di atas dapat diperoleh nilai korelasi sebesar 0,579 bertanda positif. Dengan demikian sesuai dengan ketentuan yang ada variabel motivasi secara parsial memiliki tingkat hubungan atau pengaruh yang sedang terhadap kinerja karyawan.

Tabel 12 Hasil Uji Korelasi Antara Motivasi
$\left(\mathrm{X}_{1}\right)$ Terhadap Kinerja Karyawan $(\mathrm{Y})$
\begin{tabular}{|c|c|r|r|r|} 
Model Summary \\
Model & R & R Square & $\begin{array}{c}\text { Adjusted R } \\
\text { Square }\end{array}$ & $\begin{array}{l}\text { Std. Error of the } \\
\text { Estimate }\end{array}$ \\
\hline & $.684^{a}$ & .468 & .450 & 3.114 \\
\hline
\end{tabular}

Sumber : Data Primer yang telah diolah

Berdasarkan hasil uji pada tabel di atas dapat diperoleh nilai korelasi sebesar 0,684 bertanda positif. Dengan demikian sesuai dengan ketentuan yang ada variabel disiplin kerja dan motivasi secara bersama-sama memiliki tingkat hubungan atau pengaruh yang kuat terhadap kinerja karyawan.

\section{Analisis Koefisien Determinasi}

Analisis koefisien deteminasi digunakan untuk mengetahui kontribusi besarnya pengaruh antara variabel bebas terhadap variabel terikat, dalam penelitian ini adalah variabel disiplin kerja dan motivasi baik secara parsial maupun secara bersama-sama terhadap kinerja karyawan. Adapun hasil pengolahan data dapat dijelaskan sebagai berikut :
Tabel 13 Hasil Uji Determinasi Pengaruh

Disiplin Kerja $\left(\mathrm{X}_{1}\right)$ Terhadap Kinerja

$$
\begin{aligned}
& \text { Karyawan }(\mathrm{Y}) \\
& \text { Model Summary }
\end{aligned}
$$

\begin{tabular}{|c|c|r|r|r|}
\hline Model & R & R Square & $\begin{array}{c}\text { Adjusted R } \\
\text { Square }\end{array}$ & $\begin{array}{c}\text { Std. Error of the } \\
\text { Estimate }\end{array}$ \\
\hline 1 & $.628^{a}$ & .394 & .384 & 3.296 \\
\hline
\end{tabular}

Sumber : Data Primer yang telah diolah

Berdasarkan hasil uji pada tabel di atas dapat dilihat bahwa nilai $R$ Square sebesar 0,394 atau $39,4 \%$. Hal ini menunjukkan bahwa kontribusi pengaruh disiplin kerja secara parsial terhadap kinerja karyawan adalah sebesar $39,4 \%$, sedangkan sisanya sebesar $60,6 \%$ dipengaruhi oleh faktor lain yang tidak diteliti.

Tabel 14 Hasil Uji Koefisien Determinasi Pengaruh Motivasi $\left(\mathrm{X}_{2}\right)$ Terhadap Kinerja

Karyawan (Y)

Model Summary

\begin{tabular}{|l|r|r|r|c|}
\hline Model & R & R Square & $\begin{array}{c}\text { Adjusted R } \\
\text { Square }\end{array}$ & $\begin{array}{c}\text { Std. Error of the } \\
\text { Estimate }\end{array}$ \\
\hline 1 & $.579^{a}$ & .335 & .324 & 3.453 \\
\hline
\end{tabular}

Sumber : Data Primer yang telah diolah

Dari tabel di atas dapat dilihat bahwa nilai $R$ Square sebesar 0,335 atau $33,5 \%$. Hal ini menunjukkan bahwa pengaruh motivasi secara parsial terhadap kinerja karyawan adalah sebesar 33,5\%, sedangkan sisanya sebesar $66,5 \%$ dipengaruhi oleh faktor lain yang tidak diteliti.

Tabel 15 Hasil Uji Koefisien Determinasi Pengaruh Disiplin Kerja $\left(\mathrm{X}_{1}\right)$ dan Motivasi $\left(\mathrm{X}_{2}\right)$

Terhadap Kinerja Karyawan (Y). Model Summary

\begin{tabular}{|l|r|r|r|r|}
\hline Model & \multicolumn{1}{|c|}{$\mathbf{R}$} & R Square & $\begin{array}{c}\text { Adjusted R } \\
\text { Square }\end{array}$ & $\begin{array}{c}\text { Std. Error of the } \\
\text { Estimate }\end{array}$ \\
\hline 1 & $.684^{a}$ & .468 & .450 & 3.114 \\
\hline
\end{tabular}

Sumber : Data Primer yang telah diolah

Dari tabel di atas dapat dilihat bahwa nilai $R$ Square sebesar 0,468 atau $46,8 \%$. Hal ini menunjukkan bahwa pengaruh disiplin kerja dan motivasi secara bersama-sama terhadap kinerja karyawan adalah sebesar 46,9\%, sedangkan sisanya sebesar 53,2\% dipengaruhi oleh 
faktor lain yang tidak diteliti.

\section{Pengujian Hipotesis}

Hipotesis penelitian dapat diartikan sebagai jawaban yang bersifat sementara terhadap masalah penelitian, sampai terbukti melalui data yang terkumpul dan harus diuji secara empiris yang diperoleh melalui pengumpulan data. Maka pengujian hipotesis dilakukan melalui:

\section{a. Uji Hipotesis Parsial (Uji t)}

Pengujian hipotesis secara parsial menggunakan uji t yaitu untuk menguji bagaimana pengaruh masing-masing variabel bebas secara sendiri-sendiri terhadap variabel terikatnya.

Hipotesis Pertama : Terdapat pengaruh positif dan signifikan antara disiplin kerja terhadap kinerja karyawan pada PT. Bank Rakyat Indonesia Cabang Pamulang.

Tabel 16 Pengujian Hipotesis Variabel Disiplin kerja $\left(\mathrm{X}_{1}\right)$ Terhadap Kinerja Karyawan $(\mathrm{Y})$

\section{Coefficients $^{\mathrm{a}}$}

\begin{tabular}{|c|c|c|c|c|c|c|}
\hline & \multirow{2}{*}{ Model } & \multicolumn{2}{|c|}{$\begin{array}{l}\text { Unstandardized } \\
\text { Coefficients }\end{array}$} & \multirow{2}{*}{\begin{tabular}{|c|}
$\begin{array}{c}\text { Standardized } \\
\text { Coefficients }\end{array}$ \\
Beta
\end{tabular}} & \multirow{2}{*}{$\mathrm{t}$} & \multirow{2}{*}{ Sig. } \\
\hline & & B & $\begin{array}{l}\text { Std. } \\
\text { Error }\end{array}$ & & & \\
\hline \multirow[t]{2}{*}{1} & (Constant) & 22.823 & 3.958 & & 5.767 & .000 \\
\hline & $\begin{array}{l}\text { Motivasi } \\
\left(X_{1}\right)\end{array}$ & .521 & .085 & .628 & 6.145 & .000 \\
\hline
\end{tabular}

Sumber : Data Primer yang telah diolah

Berdasarkan hasil pengolahan data di atas, diperoleh nilai $t_{\text {hitung }}>\mathrm{t}_{\text {tabel }}$ atau $(6.145$ $>$ 2.002), hal itu juga diperkuat dengan signifikansi $0,000<0,05$, hal itu juga diperkuat dengan nilai signifikansi $0,000<$ 0,05 . Dengan demikian hipotesis pertama yang menyatakan terdapat pengaruh positif dan signifikan antara disiplin kerja terhadap kinerja karyawan pada PT. Bank Rakyat Indonesia Cabang Pamulang dapat diterima.

Hipotesis Kedua : Terdapat pengaruh positif dan signifikan antara motivasi terhadap kinerja karyawan pada PT. Bank Rakyat Indonesia Cabang Pamulang.
Tabel 17 Pengujian Hipotesis Variabel Motivasi

Terhadap Kinerja Karyawan (Y)

Coefficients $^{\mathrm{a}}$

\begin{tabular}{|c|c|c|c|c|c|c|}
\hline & \multirow{2}{*}{ Model } & \multicolumn{2}{|c|}{$\begin{array}{c}\text { Unstandardized } \\
\text { Coefficients }\end{array}$} & \multirow{2}{*}{$\begin{array}{c}\begin{array}{c}\text { Standardized } \\
\text { Coefficients }\end{array} \\
\text { Beta }\end{array}$} & \multirow{2}{*}{$\mathrm{t}$} & \multirow{2}{*}{ Sig. } \\
\hline & & B & $\begin{array}{l}\text { Std. } \\
\text { Error }\end{array}$ & & & \\
\hline \multirow[t]{2}{*}{1} & (Constant) & 23.322 & 4.402 & & 5.298 & .000 \\
\hline & $\begin{array}{l}\text { Motivasi } \\
\left(\mathrm{X}_{2}\right)\end{array}$ & .513 & .095 & .579 & 5.407 & .000 \\
\hline
\end{tabular}

Sumber : Data Primer yang telah diolah

Berdasarkan hasil pengolahan data di atas, diperoleh nilai $t_{\text {hitung }}>\mathrm{t}_{\text {tabel }}$ atau (5.407 $>2.002$ ), hal itu juga diperkuat dengan nilai signifikansi $0,000<0,05$. Dengan demikian hipotesis kedua yang menyatakan terdapat pengaruh positif dan signifikan antara disiplin kerja terhadap kinerja karyawan pada PT. Bank Rakyat Indonesia Cabang Pamulang dapat diterima.

\section{b. Uji Hipotesis Secara Simultan (Uji F)}

Pengujian hipotesis secara simultan dimaksudkan untuk mengetahui pengaruh semua variabel bebas terhadap variabel terikat yaitu disiplin kerja dan motivasi terhadap kinerja karyawan. Dalam pengujian ini digunakan uji $\mathrm{F}$.

Hipotesis Ketiga : Terdapat pengaruh positif dan signifikan antara disiplin kerja dan motivasi secara simultan terhadap kinerja karyawan pada PT. Bank Rakyat Indonesia Cabang Pamulang.

Adapun hasil pengujiannya sebagai berikut:

Tabel 18 Pengujian Hipotesis Secara Simultan

ANOVA $^{a}$

\begin{tabular}{|l|l|r|r|r|c|c|}
\multicolumn{2}{c|}{ Model } & $\begin{array}{c}\text { Sum of } \\
\text { Squares }\end{array}$ & df & $\begin{array}{c}\text { Mean } \\
\text { Square }\end{array}$ & F & Sig. \\
\hline \multirow{2}{*}{1} & Regression & 487.185 & 2 & 243.592 & 25.116 & $.000^{\mathrm{b}}$ \\
\cline { 2 - 7 } & Residual & 552.815 & 57 & 9.699 & & \\
\cline { 2 - 7 } & Total & 1040.000 & 59 & & & \\
\hline
\end{tabular}

Sumber : Data Primer diolah

Berdasarkan hasil pengolahan data di atas, diperoleh nilai $\mathrm{F}_{\text {hitung }}$ lebih besar dari 
$\mathrm{F}_{\text {tabel }}$ atau $(25.116>2.770)$, dengan demikian hipotesis ketiga yang menyatakan terdapat pengaruh positif dan signifikan antara disiplin kerja dan motivasi secara simultan terhadap kinerja karyawan pada PT. Bank Rakyat Indonesia Cabang Pamulang dapat diterima.

\section{PEMBAHASAN DAN HASIL}

Dari hasil pengujian statistik dan analisis di atas, maka dapat dipaparkan analisis pengaruh disiplin kerja dan motivasi terhadap kinerja karyawan pada PT. Bank Rakyat Indonesia Cabang Pamulang, sebagai berikut :

1. Pengaruh Disiplin kerja Terhadap Kinerja Karyawan Pada PT. Bank Rakyat Indonesia Cabang Pamulang.

Diperoleh model regresi adalah $\mathrm{Y}=$ $22,823+0,521 \mathrm{X}_{1}$, dimana nilai koefisien beta bernilai positif, artinya apabila disiplin kerja mengalami peningkatan maka kinerja karyawan juga akan meningkat.

Nilai koefisien korelasi antara disiplin kerja terhadap kinerja karyawan adalah sebesar 0,628. Dapat dikatakan bahwa kedua variabel memiliki hubungan yang positif sebesar 0,628 dengan tingkat hubungan atau pengaruh kuat antara variabel disiplin kerja dengan kinerja karyawan pada PT. Bank Rakyat Indonesia Cabang Pamulang.

Nilai koefisien determinasi diperoleh sebesar 0,394 , data tersebut mengindikasikan bahwa variabel disiplin kerja memberikan kontribusi pengaruh sebesar 39,4\% terhadap kinerja karyawan pada PT. Bank Rakyat Indonesia Cabang Pamulang.

Pengujian hipotesis diperoleh $\mathrm{t}_{\text {hitung }}>$ $\mathrm{t}_{\text {tabel }}$ atau $(6,145>2,002)$ dan signifikansi $\mathrm{t}<$ 0,05 atau $(0,000<0,05)$. Dengan demikian hipotesis $\mathrm{H} 1$ yang penulis ajukan dapat diterima. Hal ini menunjukkan bahwa disiplin kerja berpengaruh positif dan signifikan terhadap kinerja karyawan pada PT. Bank Rakyat Indonesia Cabang Pamulang.
2. Pengaruh Motivasi Terhadap Kinerja Karyawan Pada PT. Bank Rakyat Indonsia Cabang Pamulang.

Diperoleh model persamaan regresi adalah $\mathrm{Y}=22,322+0,513 \mathrm{X}_{1}$, dimana nilai koefisien beta bernilai positif, artinya apabila motivasi mengalami peningkatan maka kinerja karyawan juga akan meningkat.

Nilai koefisien korelasi antara motivasi terhadap kinerja karyawan adalah sebesar 0,479. Dapat dikatakan bahwa kedua variabel memiliki hubungan yang positif sebesar 0,579 dengan tingkat hubungan atau pengaruh sedang antara variabel motivasi dengan kinerja karyawan pada PT. Bank Rakyat Indonesia Cabang Pamulang.

Nilai koefisien determinasi diperoleh sebesar 0,335 , data tersebut mengindikasikan bahwa variabel motivasi memberikan kontribusi pengaruh sebesar 33,5\% terhadap kinerja karyawan pada PT. Bank Rakyat Indonesia Cabang Pamulang.

Pengujian hipotesis diperoleh $\mathrm{t}_{\text {hitung }}>$ $\mathrm{t}_{\text {tabel }}$ atau $(5,407>2,002)$ dan signifikansi $\mathrm{t}<$ 0,05 atau $(0,000<0,05)$. Dengan demikian hipotesis $\mathrm{H} 2$ yang penulis ajukan dapat diterima. Hal ini menunjukkan bahwa motivasi berpengaruh positif dan siginifikan terhadap kinerja karyawan pada PT. Bank Rakyat Indonesia Cabang Pamulang.

3. Pengaruh Disiplin Kerja dan Motivasi secara bersama-sama Terhadap Kinerja Karyawan Pada PT. Bank Rakyat Indonesia Cabang Pamulang.

Diperoleh model regresi yang diperoleh adalah $\mathrm{Y}=16,493+0,367 \mathrm{X}_{1}+0,292 \mathrm{X}_{2}$, dimana nilai koefisien beta masing-masing variabel bernilai positif, artinya apabila disiplin kerja dan motivasi mengalami peningkatan maka kinerja karyawan juga akan meningkat.

Nilai koefisien korelasi antara disiplin kerja dan motivasi terhadap kinerja kar- 
yawan adalah sebesar 0,684. Dapat dikatakan bahwa kedua variabel memiliki hubungan yang positif sebesar 0,684 dengan tingkat hubungan atau pengaruh kuat antara variabel disiplin kerja dan motivasi dengan kinerja karyawan pada PT. Bank Rakyat Indonesia Cabang Pamulang.

Nilai koefisien determinasi diperoleh sebesar sebesar 0,468. Data tersebut mengindikasikan bahwa disiplin kerja dan motivasi secara bersama-sama memberikan kontribusi pengaruh sebesar $46,8 \%$ terhadap kinerja karyawan pada PT. Bank Rakyat Indonesia Cabang Pamulang, selebihnya sebesar $53,2 \%$ dipengaruhi oleh variabel lain yang tidak diteliti. Pengujian hipotesis secara simultan $\mathrm{F}_{\text {hitung }}>\mathrm{F}_{\text {tabel }}$ $(25,116>2,770)$ dan F signifikansi $<0,05$ $(0,000<0,05)$. Dengan demikian hipotesis $\mathrm{H} 3$ yang penulis ajukan dapat diterima. Hal ini menunjukkan bahwa variabel disiplin kerja dan motivasi secara bersamasama berpengaruh positif dan siginifikan terhadap kinerja karyawan pada PT. Bang Rakyat Indonesia Cabang Pamulang.

\section{KESIMPULAN, IMPLIKASI DAN SARAN \\ Kesimpulan}

Setelah penulis melakukan penelitian dan analisis mengenai pengaruh disiplin kerja dan motivasi terhadap kinerja karyawan pada PT. Bang Rakyat Indonesia Cabang Pamulang, seperti yang telah dipaparkan pada bab-bab sebelumnya, maka penulis dapat menarik kesimpulan sebagai berikut :

1. Disiplin kerja berpengaruh positif dan signifikan terhadap kinerja karyawan pada PT. Bank Rakyat Indonesia Cabang Pamulang. Hal ini dapat dilihat dari Nilai $\mathrm{t}_{\text {hitung }}>\mathrm{t}_{\text {tabel }}$ $(6,145>2,002)$ dan signifikansi $t<0,05$ $(0,000<0,05)$ disiplin kerja mempunyai korelasi positif dengan kinerja karyawan sebesar 0,628. Disiplin kerja mempunyai kontribusi pengaruh sebesar 39,4\% terhadap kinerja karyawan. Model regresi sederhana yang diperoleh adalah $\mathrm{Y}=22,823+0,521 \mathrm{X}_{1}$ yang diartikan apabila disiplin kerja yang dilakukan karyawan meningkat maka akan meningkatkan kinerja karyawan pada PT. Bank Rakyat Indonesia Cabang Pamulang.

2. Motivasi berpengaruh positif dan signifikan terhadap kinerja karyawan pada PT. Bank Rakyat Indonesia Cabang Pamulang. Hal ini dapat dilihat dari Nilai $t_{\text {hitung }}>\mathrm{t}_{\text {tabel }}(5,407$ $>2,002)$ dan signifikansi $t<0,05(0,000<$ $0,05)$ motivasi mempunyai korelasi positif dengan kinerja karyawan sebesar 0,579. Disiplin kerja mempunyai kontribusi pengaruh sebesar 33,5\% terhadap kinerja karyawan. Model regresi sederhana yang diperoleh adalah $\mathrm{Y}=23,322+0,513 \mathrm{X}_{1}$ yang diartikan apabila motivasi yang dilakukan karyawan meningkat maka akan meningkatkan kinerja karyawan pada PT. Bank Rakyat Indonesia Cabang Pamulang.

3. Disiplin kerja dan motivasi secara bersama-sama berpengaruh positif dan signifikan terhadap kinerja karyawan pada PT. Bank Rakyat Indonesia Cabang Pamulang. Hal ini dapat dilihat dari Nilai $F_{\text {hitung }}>$ $\mathrm{F}_{\text {tabel }}(25,116>2,770)$ dan signifikansi $\mathrm{F}$ $<0,05(0,000<0,05)$. Disiplin kerja dan motivasi secara bersama-sama mem punyai kontribusi $\left(\mathrm{R}^{2}\right)$ sebesar $46,8 \%$ terhadap kinerja karyawan pada PT. Bank Rakyat Indonesia Cabang Pamulang, selebihnya sebesar 53,2\% dipengaruhi oleh variabel lain yang tidak diteliti, misalnya punishment, promosi jabatan, pelatihan dan lain-lain. Model regresi berganda yang diperoleh adalah $\mathrm{Y}=16,493+0,367 \mathrm{X}_{1}+$ $0,292 \mathrm{X}_{2}$ yang diartikan apabila disiplin kerja dan motivasi meningkat maka akan meningkatkan kinerja karyawan pada PT. Bank Rakyat Indonesia Cabang Pamulang.

\section{Implikasi}

Dari hasil kesimpulan di atas, penelitian ini memiliki implikasi sebagai berikut :

1. Agar tingkat kinerja karyawan pada PT. 
Bank Rakyat Indonesia Cabang Pamulang tetap baik, maka hendaknya variabel disiplin kerja harus diperhatikan dan ditingkatkan oleh pihak PT. Bank Rakyat Indonesia Cabang Pamulang, indikatorindikator yang ada dalam disiplin kerja harus dipahami dan dijalankan oleh semua karyawan perusahaan, sehingga semua peraturan dan kebijakan yang dibuat oleh manajemen perusahaan dapat berfungsi dengan baik, tanpa membeda-bedakan antara staff dan manajemen.

2. Agar tingkat kinerja karyawan pada PT. Bank Rakyat Indonesia Cabang Pamulang tetap tinggi maka hendaknya variabel motivasi harus diperhatikan dan ditingkatkan oleh pihak PT. Bank Rakyat Indonesia Cabang Pamulang, indikatorindikator yang ada dalam motivasi harus dipahami dan dijalankan oleh semua karyawan perusahaan. Motivasi apabila dikelola dengan tepat, kontribusi positif terhadap terwujudnya kinerja karyawan akan mengalami perkembangan yang positif sehingga tujuan perusahaan dapat dicapai.

3. Agar tingkat kinerja karyawan pada PT. Bank Rakyat Indonesia Cabang Pamulang tetap tinggi maka hendaknya variabel dan indikator-indikator disiplin kerja dan motivasi secara bersama-sama dan terintegrasi harus diperhatikan dan ditingkatkan serta dipahami oleh pihak PT. Bank Rakyat Indonesia Cabang Pamulang, guna mendukung terciptanya kondisi bank yang diakui memiliki kinerja yang sangat baik oleh nasabah, dapat menerapkan strategi pelayanan nasabah yang didukung sumber daya manusia yang handal dan penerapan teknologi yang update dan berkelanjutan sehingga pada akhirnya akan meningkatkan value perusahaan.

\section{Saran}

Berdasarkan kesimpulan di atas, maka penulis mengajukan beberapa saran yang diha- rapkan dapat bermanfaat bagi perusahaan. Adapun saran tersebut adalah sebagai berikut:

1. PT. Bank Rakyat Indonesia Cabang Pamulang harus meningkatkan usaha-usaha yang berkaitan dengan variabel disiplin kerja, memastikan semua peraturan-peraturan dan kebijakan perusahaan dijalankan oleh semua karyawan secara benar dan mempertimbangkan kepentingan karyawan sehingga dapat menambah semangat kerja yang ada pada pribadi karyawan.

2. PT. Bank Rakyat Indonesia Cabang Pamulang harus meningkatkan upaya yang berkaitan dengan variabel motivasi dengan cara memberikan tanggung jawab yang lebih jelas disesuaikan dengan tingkat kemampuan pegawai serta memberikan reward bagi pegawai yang memiliki prestasi dalam melaksanakan tugas pekerjaannya

3. PT. Bank Rakyat Indonesia Cabang Pamulang harus meningkatkan usaha-usaha yang berkaitan dengan variabelkinerja karyawan, memastikan pencapaian kerja sesuai yang diharapkan dengan menanamkan pentingnya karyawan memiliki disiplin yang tinggi, berlomba-lomba berkompetisi mencapai prestasi kerja yang lebih baik lagi dalam menunjang tujuan perusahaan. Bagi peneliti selanjutnya disarankan dapat memperdalam penelitian dengan cara memperbaiki indikator yang masih tidak baik atau dengan menambah indikator pertanyaan dan jumlah responden penelitian sehingga akan dapat lebih diketahui variabel yang paling memberikan kontribusi positif bagi perusahaan.

\section{DAFTAR PUSTAKA}

Bilson, Simamora, 2014, "Panduan Riset Prilaku Konsumen", Jakarta, PT. Gramedia Pustaka.

Gerry, Dessler, 2000 "Human Resources Management", Prenticehall, International Inc, London.

Hasibuan, 2012, "Manajemen Sumber Daya Manusia", Jakarta, Haji Masagung. 
Imam, Ghozali, 2011 "Aplikasi Analisis Multivariate dengan Program SPSS", Semarang, Edisi Kelima, Badan Penerbit Undip.

Imam, Ghozali, 2013 "Aplikasi Analisis Multivariate dengan Program SPSS", Semarang, Edisi Kelima, Badan Penerbit Undip.

Inpres No.6/2014, tentang peningkatan daya saing menghadapi Masyarakat Ekonomi ASEAN.

Keputusan Presiden No.37/2014 tentang regulasi pemerintah dalam upaya untuk meningkatkan daya saing nasional dan menghadapi MEA.

Levy, P.E, 2000, "Industrial Organization Psycology", Miffilin Company Boston Houghton.

Luthans, Fred, 2006, "Organizational Behavior", McGraw-Hill, New York.

Miftah, Thoha, 2007, "Kepemimpinan Dalam Manajemen", Jakarta, Edisi Pertama, PT. Raja Grafindo.

Nachrowi Djalal, Nachrowidan Hardius Usman, 2010, “Teknik Pengambilan Keputusan". Jakarta, Penerbit PT. Grasindo.

Nawawi, 2006, "Sumber Daya Manusia untuk Bisnis yang Kompetitif”, Jakarta, Prehalindo.

Peraturan Bank Rakyat Indonesia tahun 1998 tentang disiplin karyawan bank.

Robbins, S. \& Judge, T, 2008, "Organizational Behavior”, Edisi keduabelas, Prentice Hall.

Safroni, Ladzi, 2012, "Manajemen dan Reformasi Pelayanan Publik dalam Konteks Birokrasi Indonesia", Surabaya.

Salam, Darma Setyawan, 2007, "Manajemen Pemerintahan Indonesia”, Jakarta, Djambatan.

Sarwono, Jonathan, 2012, "Metode Penelitian Kuantitatif Dan Kualitatif”, Yogyakarta, Graha Ilmu.

Singgih Santoso, 2010, "SPSS Statistik Parametik”, Jakarta, Cetakan Kedua, PT. Elek Media.

Sondang P, Siagian, 2010, "Kiat Meningkatkan Produktivitas Kerja”, Jakarta, PT. Rineka Cipta.
Sugiyono, 2012 "Metode Penelitian Kuantitatif Kualitatif dan $R$ \& D”, Bandung, Penerbit CV. Alfabeta.

Sugiyono, 2014 "Metode Penelitian Kuantitatif Kualitatif dan $R$ \& D", Bandung, Penerbit CV. Alfabeta.

Suharsimi Arikunto, 2010 "Prosedur Penelitian Suatu Pendekatan Praktek", Jakarta. PT. Rineka Cipta.

Sutrisno,Edy, 2012, "Sumber Daya Manusia", Surabaya, PT. Gramedia.

Umar, Husen, 2008, "Riset Pemasaran Dan Perilaku Konsumen”, Jakarta, PT. Gramedia Pustaka Utama.

Undang-Undang Dasar Negara Republik Indonesia Tahun 1945.

Undang-Undang Perbankan No. 7 tahun 1992 dan Peraturan Pemerintah RI No. 21 tahun 1992 tentang status Bank Rakyat Indonesia berubah menjadi perseroan terbatas.

Undang-Undang Perbankan No.10 tahun 1998 Pasal 1 tentang badan usaha yang menghimpun dana dari masyarakat dalam bentuk simpanan dan perlindungan nasabah.

Wawan S. Suherman, 2004, "Kurikulum Berbasis Kompetensi Pendidikan Jasmani Teori dan Praktik Pengembangan", Yogyakarta, FIK UNY.

Wibowo, 2009, "Manajemen Kinerja", Jakarta, PT. Raja Grafindo Persada.

Windy Aprilia dan Gunasti Hudiwinarsih, 2012, "Teori Kompensasi, Motivasi dan Komitmen Organisasi", Jakarta, Gramedia.

Wirawan, 2009, "Evaluasi Kinerja Sumber Daya Manusia (Teori Aplikasi dan Penelitian)". Jakarta, Salemba Empat. 